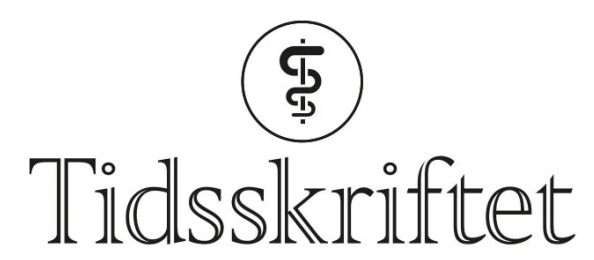

DEN NORSKE LEGEFORENING

\title{
La trygdesøkeren skrive sin egen erklæring
}

KRONIKK

\section{GURI AARSETH}

guriseth@gmail.com

Guri Aarseth er ph.d., spesialist i allmennmedisin og tidligere fastlege ved Sentrum legekontor i

Larvik. Hun er nå pensjonist.

Forfatteren har fylt ut ICMJE-skjemaet og oppgir ingen interessekonflikter.

\section{Pasienten, ikke legen, bør ha rett og plikt til å redegjøre overfor Nav for hvordan sykdom påvirker arbeidsevnen.}

I vårt liberale samfunn står idealet om pasientens medbestemmelse og autonomi sterkt. Modellen fungerer fordi den er humanistisk, effektiv og rasjonell. Paternalisme, derimot, bygger på at individet ikke alltid vet sitt eget beste. I folketrygdloven og Nav fungerer paternalisme også som beskyttelse av fellesskapets ressurser: Velferdstjenester er primært innrettet med tanke på å få folk i jobb og redusere økningen av trygdemottakere (arbeidslinja). Leger opptrer derfor overstyrende i trygdemedisinske konsultasjoner (1) . Legens pålagte oppgave med å dokumentere medisinsk forklart arbeidsuførhet overfor Nav innebærer imidlertid, etter mitt syn, en form for paternalisme som er lite funksjonell både for legen, pasienten og Nav.

Kravet til leger om å dokumentere pasientens funksjons- og inntektsevne hviler på en implisitt antagelse om at pasientens stemme - i motsetning til legens - ikke er troverdig eller saklig (objektiv). Jeg vil argumentere for at uføretrygdsøkeren i utgangspunktet er troverdig og kompetent til å redegjøre for sin alminnelige og spesifikke funksjonsevne og for sin (reduserte) mulighet til å skaffe seg en inntekt. En pasientegenerklæring bør innføres i uføresaker og være dokumentasjon på lik linje med fastlegens medisinske ekspertise.

\section{Fastlegens problem}

Den norske fastlegens autoritative rolle i trygdesaker som gjelder egne pasienter er enestående i Europa (므). Å skrive legeerklæringer for Nav er en oppgave som er pålagt fastlegen, men som ofte utføres i en negativt ladet kontekst. Forskning i Norge, Sverige og Storbritannia viser at allmennleger ofte opplever sakkyndighetsoppgaven som en byrde (3), en kilde til konflikt med pasienten (4-7.) og at «riktig» kommunikasjon med Nav er 
krevende (모). Allmennleger har liten tid og interesse for "papirarbeid» (9.) og er misnøyde med honoreringen (taksten tilsvarer kun 40 minutters arbeid). De opplever det

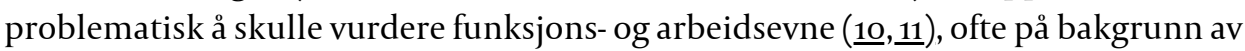

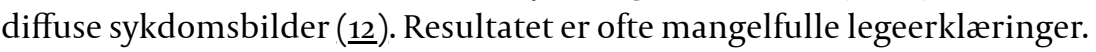

\section{«Uføretrygdsøkeren er i utgangspunktet troverdig og kompetent til å redegjøre for sin alminnelige og spesifikke funksjonsevne og for sin (reduserte) mulighet til å skaffe seg en inntekt»}

For Nav er beskrivelsen av funksjonsevne "gullet» i en trygdeerklæring. Folketrygdloven bygger imidlertid på den antakelsen at fastleger vet hvordan pasienten fungerer $\mathrm{i}$ privatlivet (13), noe de selvsagt ikke vet og ikke kan vite. Antakelsen står i motsetning til kravet om en verifiserbar (objektiv) erklæring som bygger på saklighet og reell innsikt. Gapet mellom lovtekst og klinisk virkelighet er trolig en av forklaringene på at mange av legeerklæringene ikke innfrir kravene til å være utfyllende og verifiserbare (14-16). Men til tross for sine mangler er legeerklæringen et av Navs viktigste dokumenter i uføresaker (11, 17.).

\section{Pasienten uten direkte stemme}

Kommunikasjonen (legeerklæringen) i en uføresak foregår i prinsippet over hodet på pasienten, mellom fastlegen/spesialisten og Nav. Den som skriver (legen) har saklig sett ingen interesse av sakens utfall. Den som tolker teksten og avgjør saken (regionale Nav), møter aldri pasienten. Den det skrives om (pasienten), kommer ikke direkte til orde i teksten.

Hvor stor vekt Nav skal legge på legens tekst i den samlede avveiningen, vil blant annet avhenge av kvaliteten på det arbeidet som legen har gjort. Dette fastslo Høyesterett i en dom i 2019, der Nav fikk medhold i å avvise en sykmelding på grunn av manglende dokumentasjon av arbeidsuførheten (프). Pasienten er altså avhengig av at legen gjør et grundig arbeid og i tillegg er en tydelig og dyktig formidler av pasientens opplevde virkelighet og av sine egne faglige vurderinger.

\section{Subjektivitet og objektivitet}

Fremfor å være objektiv vet vi at pasientens egenvurdering er rotfestet i den subjektive opplevelsen av symptomer, i hans eller hennes estimering av seg selv, sitt miljø, sine ressurser og interesser. Pasienten er, med svært få unntak, den som best kan gi oss et bilde av sin verden - det tilhører pasientens språksone, for å bruke litteraturviteren Mikhail Bakhtins begrep (19). Å inkludere pasientens språksone, og dermed gi det subjektive legitimitet, er i harmoni med en holistisk tilnærming i medisinen. I tillegg skal pasienten i prinsippet samtykke i hva som kan og hva som bør stå i en legeerklæring om ham eller henne, og hva han eller hun ikke ønsker formidlet til Nav. I et trygdeløp får pasienten en viss anledning til å fremstille seg selv overfor Nav, enten muntlig eller ved å fylle ut skjemaer, men det har ikke autoritet som dokumentasjon. Det er legens uttalelse, ikke pasientens, som er autoritativ etter folketrygdloven og for Navs praksis.

«Pasienten er, med svcert få unntak, den som best kan gi oss et bilde av sin verden» 
Med legeerklæringen bidrar fastlegen med sitt språkunivers: opplysninger om diagnose, sykdomsprognose og behandling. For å beskrive pasientens reelle funksjonsnivå og arbeidsevne må fastlegen, i dagens system, $i$ hovedsak låne fortellingen fra pasientens språklige univers, men samtidig utgi det for å være legens egen diskurs.

\section{Legens troverdighet på spill}

«Beskriv hvordan funksjonsevnen generelt er nedsatt på grunn av sykdom», heter det $\mathrm{i}$ punkt 5.1 i Legeerklcering ved arbeidsuførhet. Men hvordan et menneske fungerer i dagliglivet kan ikke verifiseres av legen som noe observerbart, det blir kun legens versjon av pasientens narrativ (i den grad narrativet er innhentet). Dette er det vanskeligste punktet $\mathrm{i}$ legeerklæringen, ettersom det kan skape rollekonflikt. Leger unnlater ofte å gi en funksjonsvurdering, noe som er forståelig, men problematisk. Å gi en «medisinsk begrunnet vurdering av funksjons- og arbeidsevnen» og å skulle uttale seg om årsakssammenheng bør derfor ikke pålegges fastlegen. Legens profesjonelle integritet trues når Navs behov for informasjon tøyer grensene for legens kompetanse.

\section{Legeerklæringens problem}

Arbeidsuførheten må etter loven «klart skyldes sykdom». Fastleger vet imidlertid at det sjelden finnes noen entydig medisinsk årsak til arbeidsuførhet. Alle blir syke og arbeidsuføre i en gitt kontekst. Men hvis legen gir opplysninger om familiære og sosiale belastninger, er dette ikke bare irrelevant etter folketrygdloven, men kan feiltolkes av Nav og dermed skade pasientens sak.

Mange leger tyr til en bevisst «Nav-forlikelig» retorikk i trygdesaker, og - i mangel av verifiserbare medisinske fakta - fors $\emptyset$ ker de å overbevise om at pasienten bør ha uføretrygd (ㅁ). Dette medfører ofte ensidig og subtil språkbruk. I mitt doktorgradsarbeid om språket i legeerklæringer fant jeg at leger legger sterk vekt på pasientens symptomer og tilstander, tilsynelatende etter prinsippet om at jo flere symptomer og tilstander, jo bedre tjener dette

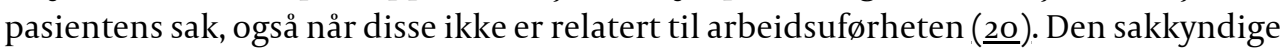
fastlegen skriver pasienten ned til en passiv bærer av symptomer og fremstiller ham eller henne som mislykket eller ikke-eksisterende som handlende individ - oftest uten å gi en

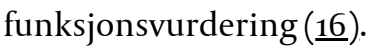

Noen legeerklæringstekster antyder at det er uenighet mellom pasienten og legen om berettigelsen av uføretrygd. Dette kan komme indirekte til uttrykk, for eksempel som ironisk pregede gjengivelser av pasientens utsagn (10 $)$. Motsatt, når legen forsøker å hjelpe pasienten til å få uføretrygd, kan legeerklæringen inneholde appeller til leseren om å innvilge uføretrygd. Trygdesøkeren kan i slike tilfeller bli fremhevet som «verdig», det vil si at han eller hun har gode verdier som gir uttelling i Nav (motivasjon, arbeidsvilje osv.) (17.). Dette er retorikk i tråd med å opptre som pasientens advokat, men i Nav er det som kjent sykdom som årsak til svekket funksjonsevne som har den høyeste verdien.

$$
\begin{aligned}
& \text { «En mangelfull erklcering fär ingen konsekvenser for legen som } \\
& \text { sakkyndig, fordi en legeerklcering i seg selv ikke er underlagt } \\
& \text { forvaltningsrett» }
\end{aligned}
$$

Det forekommer selvmotsigelser og irrelevant informasjon, både om trygdesøkeren og dennes familie. Legeerklæringer kan inneholde opplysninger som er utilsiktet krenkende

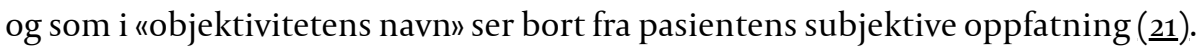


Folketrygdloven (§ 8.1) krever legeerklæring ved arbeidsuførhet, men det er intet krav om at pasienten skal medvirke eller samtykke i utformingen av legeerklæringen.

Trygdesøkeren må forutsette at legen formidler saken utfyllende og korrekt. Nav returnerer overraskende sjelden en legeerklæring på grunnlag av dens feil og mangler. I stedet får

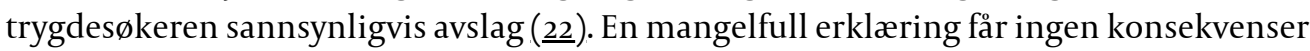
for legen som sakkyndig, fordi en legeerklæring i seg selv ikke er underlagt forvaltningsrett.

\section{Rett til å skrive sin sak}

Pasienten bør, så langt det er mulig for ham eller henne, ha både rett og plikt til å representere seg selv. Som for private forsikringssaker bør det innføres en pasientegenerklæring som underlegges de samme juridiske kravene til korrekthet og verifiserbarhet som legeerklæringen. Den skal ha samme legitimitet og dokumenterende styrke som legens medisinske opplysninger. Pasienten bør bli medforfatter av erklæringen. Dette bør skje i et eget, adskilt format, slik at de to tekstene, legeerklæringen og pasienterklæringen, sammen gir grunnlaget for et vedtak i Nav. Legen skal ikke passivt overta pasientens perspektiv, men relatere til det som står i pasienterklæringen som pasientens egen, separate og adskilte språksone. Legen kan da begrense sitt bidrag til å informere om diagnose, medisinsk behandling og sykdomsprognose samt kommentere pasientens egen utlegning der det er medisinsk aktuelt. Bruk av pasientegenerklæring kan praktiseres innenfor dagens ordning, men bør tas inn i folketrygdloven for å sikre pasienten denne rettigheten.

\section{Fordeler ved å styrke pasientens ansvar}

For trygdesøkeren vil rett og plikt til selvrepresentasjon overfor Nav innebære at han eller hun selv får selektere og vektlegge informasjon om sin helse, funksjonsevne og arbeidsevne og begrense informasjon om sitt privatliv. Det vil løfte pasienten/trygdesøkeren fra en posisjon som passivisert objekt til et medvirkende, autonomt og ansvarlig subjekt som har rett til å snakke direkte på egne vegne.

$$
\begin{aligned}
& \text { «Bruk av pasientegenerklcering kan gjennomføres innenfor dagens } \\
& \text { ordning, men bør tas inn i folketrygdloven for å sikre pasienten denne } \\
& \text { rettigheten» }
\end{aligned}
$$

For legen vil pasientens egenerklæring trolig ha positive følger. Legen kan holde seg til sin medisinskfaglige kompetanse og overlate til pasienten å beskrive sine symptomer, funksjonsevne og arbeidsevne. Det vil trolig resultere i mindre tidsbruk, redusere legens stress og «advokat»-virksomhet og gi færre konflikter med pasienter.

Fra Nav sitt perspektiv kan pasientens egenerklæring, adskilt fra legens medisinske, bety en mer troverdig og eksakt beskrivelse av tapt funksjonsevne. En tydelig adskillelse av kildene for informasjon gjør at man ikke lenger trenger å spekulere på hva som er pasientens utsagn og hva som er legens vurdering. Nav-skjemaet Legeerklcering ved arbeidsuførhet bør revideres, og det bør i tillegg utarbeides et nytt format som er forbeholdt en egenerklæring fra pasienten.

\section{LITTERATUR}

1. Solli HM. Personsentrert trygdemedisin i etiske perspektiver.Sykdom, funksjonsevne og objektive erklæringer. Oslo: Norsk trygdemedisinsk forening, 2020. 
2. Hemmings P, Prinz C. Sickness and disability systems: comparing outcomes and policies in Norway with those in Sweden, the Netherlands and Switzerland. Paris: OECD, 2020.

http://www.oecd.org/officialdocuments/publicdisplaydocumentpdf/?

cote $=\mathrm{ECO} / \mathrm{WKP}(2020) 9 \&$ docLanguage $=$ En Lest 19.1.2021.

3. Gulbrandsen P, Førde R, Aasland OG. Hvordan har legen det som portvakt? Tidsskr Nor Lægeforen 2002; 122: 1874-9. [PubMed]

4. Gerner U, Alexanderson K. Issuing sickness certificates: a difficult task for physicians: a qualitative analysis of written statements in a Swedish survey. Scand J Public Health 2009; 37: 57-63. [PubMed] [CrossRef]

5. Nilsen S, Malterud K. What happens when the doctor denies a patient's request? A qualitative interview study among general practitioners in Norway. Scand J Prim Health Care 2017; 35: 201-7. [PubMed][CrossRef]

6. Engblom M, Nilsson G, Arrelöv B et al. Frequency and severity of problems that general practitioners experience regarding sickness certification. Scand J Prim Health Care 2011; 29: 227-33. [PubMed][CrossRef]

7. Wynne-Jones G, Mallen CD, Main CJ et al. What do GPs feel about sickness certification? A systematic search and narrative review. Scand J Prim Health Care 2010; 28: 67-75. [PubMed][CrossRef]

8. Rasmussen EB. Rhetorical work and medical authority: Constructing convincing cases in insurance medicine. Soc Sci Med 2020; 264: 113324. [PubMed][CrossRef]

9. EY og Vista Analyse. Evaluering av fastlegeordningen. Oslo: Helsedirektoratet, 2019. https://vistaanalyse.no/site/assets/files/6663/evaluering-av-fastlegeordningen---sluttrapport-fra-ey-og-vistaanalyse.pdf Lest 19.1.2021.

10. Aarseth G, Natvig B, Engebretsen E et al. 'Working is out of the question': a qualitative text analysis of medical certificates of disability. BMC Fam Pract 2017; 18: 55. [PubMed][CrossRef]

11. Gjersøe H. Komplekse vurderinger i førstelinjen - en studie av arbeidsevnevurdering som aktiveringspolitisk virkemiddel. Ph.d.-avhandling. Oslo: Høgskolen i Oslo og Akershus, 2017.

12. $\emptyset$ verland R, $\emptyset$ verland $S$, Johansen $\mathrm{KN}$ et al. Verifiability of diagnostic categories and work ability in the context of disability pension award: a survey on "gatekeeping" among general practitioners in Norway. BMC Public Health 2008; 8: 137. [PubMed][CrossRef]

13. NAV. Hvilke helseopplysninger og legeerklæringer trenger NAV - uføretrygd.

https://www.nav.no/no/nav-og-samfunn/samarbeid/leger-og-andre-behandlere/uforetrygd-

informasjon-for-leger/hvilke-helseopplysninger-og-legeerklaeringer-trenger-nav-uforetrygd_kap Lest 19.1.2021.

14. FOR-2008-12-18-1486. Forskrift om krav til helsepersonells attester, erklæringer o.l. https://lovdata.no/dokument/SF/forskrift/2008-12-18-1486 Lest 19.1.2021.

15. Kiessling A, Arrelöv B, Larsson A et al. Quality of medical certificates issued in long-term sick leave or disability in relation to patient characteristics and delivery of health care. Scand J Public Health 2013; 41: 412-20. [PubMed][CrossRef]

16. Aarseth G, Natvig B, Engebretsen E et al. Writing the patient down and out: the construal of the patient in medical certificates of disability. Sociol Health Illn 2016;38: 1379-95. [PubMed][CrossRef]

17. Aarseth G, Natvig B, Engebretsen E et al. Acting by persuasion- values and rhetoric in medical certificates of work incapacity: A qualitative document analysis. Med Humanit 2019; 45: 60-6. [PubMed][CrossRef]

18. Dom HR-2019-2336-A, sak nr 19-077805SIV-HRET. Oslo: Høyesteretten, 2020.

https://www.domstol.no/globalassets/upload/hret/avgjorelser/2019/desember-2019/hr-2019-2336-a.pdf Lest 19.1.2021.

19. Bakhtin M. Du discourse romanesque. I: Esthétique et théorie du roman. Paris: Gallimard, 1978.

20. Aarseth G. The language of work disability. A study of medical certificates written by Norwegian general practitioners. Ph.d.-avhandling. Oslo: Universitetet i Oslo, 2019. https://www.duo.uio.no/handle/10852/68312 Lest 19.1.2021.

21. Klage på legeerklæring - krenkende, sak 14/2524. I: Årsberetning for Rådet for legeetikk for perioden 1.1.2014-31.12.2014. Oslo: Den norske legeforening, 2014. https://www.legeforeningen.no/contentassets/dd412e8e185c4931877f28eoa86c3285/arsberetning2014.pdf Lest 19.1.2021.

22. Stenvaag S. Enda litt verre, lille mann. Klassekampen 20.1.2020:16-17.

https://klassekampen.no/utgave/2020-01-20/enda-litt-verre-lille-mann Lest 19.1.2021. 
Publisert: 8. februar 2021. Tidsskr Nor Legeforen. DOI: 10.4045/tidsskr.20.o814

Mottatt 9.10.2020, godkjent 20.1.2021.

(C) Tidsskrift for Den norske legeforening 2023. Lastet ned fra tidsskriftet.no 26. april 2023. 